\title{
HUBUNGAN KETERSEDIAAN SARANA DAN PELAYANAN PETUGAS DENGAN KEPUASAN PASIEN POLI KIA DI PUSKESMAS BASUKI RAHMAD KOTA BENGKULU
}

\author{
The Relationship between Availability of Facilities and Services of Staffs \\ with Satisfaction of Patient of Child and Mother Health Polyclinic in \\ Basuki Rahmad Public Health Center Bengkulu City
}

\author{
Rina Aprianti ${ }^{1}$, Sanisahhuri ${ }^{1}$, David Andrew Tambayong ${ }^{1}$ \\ ${ }^{1}$ Prodi Kesehatan Masyarakat STIKES Tri Mandiri Sakti Bengkulu \\ Email : rina.aprianti89@gmail.com
}

\section{ARTICLE HISTORY}

Received [20 Juli 2020]

Revised [27 Juli 2020]

Accepted [05 Agustus 2020]

KATA KUNCI:

kepuasan pasien, ketersediaan sarana, pelayanan petugas

\section{KEYWORDS:}

availability of facilities, satisfaction of patient, services of staffs

\section{ABSTRAK}

Kesehatan ibu dan anak menjadi target dalam Millennium Development Goals (MDGs). Program kesehatan ibu dan anak menjadi sangat penting karena ibu dan anak merupakan unsur penting pembangunan. Hal ini mengandung pengertian bahwa dari seorang ibu akan melahirkan calon-calon penerus bangsa yaitu anak. Penelitian ini bertujuan untuk mengetahui hubungan ketersediaan sarana dan pelayanan petugas dengan kepuasan pasien poli kesehatan ibu dan anak di Puskesmas Basuki Rahmad Kota Bengkulu. Jenis penelitian ini adalah Survei Analitik dengan menggunakan desain Cross Sectional. Populasi dalam penelitian ini adalah ibu yang berkunjung di poli kesehatan ibu dan anak (KIA) di Puskesmas Basuki Rahmad Kota Bengkulu. Teknik pengambilan sampel pada penelitian ini menggunakan Accidental Sampling dan diperoleh sampel sebanyak 45 ibu. Pengumpulan data dalam penelitian menggunakan data primer dan data sekunder. Teknik Analisis data dilakukan dengan analisis univariat dan bivariat dengan Uji Chi-Square. Hasil penelitian ini adalah: dari 45 ibu, terdapat 27 ibu (60,0\%) mengatakan ketersediaan sarana lengkap, 31 ibu (68,9\%) mengatakan puas dengan pelayanan petugas, dan 27 ibu (60,0\%) mengatakan puas. Penelitian ini menunjukan ada hubungan yang signifikan antara ketersediaan sarana dan pelayanan petugas dengan kepuasan pasien di poli KIA Puskesmas Basuki Rahmad Kota Bengkulu. Diharapkan bagi petugas kesehatan untuk meningkatkan sarana dan pelayanan kesehatan.

\section{ABSTRACT}

Maternal and child health is a target in the Millennium Development Goals (MDGs). Maternal and child health programs become very important because mothers and children are an important element of development. This implies that from a mother will give birth to future successors, namely children. This study aimed to determine the relationship between with satisfaction of patient of child and mother health polyclinic at Basuki Rahmad Public Health Center Bengkulu City. This type of study was an Analytical Survey used a Cross Sectional design. The population in this study was mothers who visited child mother health polyclinic at Basuki Rahmad Public Health Center Bengkulu City. The sampling technique in this study used Accidental Sampling and obtained a sample of 45 mothers. Data collection in research used primary data and secondary data. The data analysis technique was done by univariate and bivariate analysis with Chi-Square Test. The results of this study are : from 45 rmothers, there were 27 mothers $(60.0 \%)$ said that the availability of facilities was completed, 31 mothers (68.9\%) said they were satisfied with the services of staffs, and 27 mothers (60.0\%) said they were satisfied. This study showed that there was a significant relationship between availability of facilities and services of staffs and satisfaction of patient at child and mother health polyclinic in Basuki Rahmad Public Health Center Bengkulu City. It is expected that health workers can improve the facilities and health services. 


\section{Pendahuluan}

Kesehatan merupakan salah satu kebutuhan dasar manusia yang harus dipenuhi dalam usaha mewujudkan suatu tingkat kehidupan masyarakat secara optimal. Upaya kesehatan yang semula dititik beratkan pada penyembuhan penderitaan secara berangsur-angsur berkembang kearah keterpaduan upaya kesehatan yang menyeluruh. Oleh karena itu, pembangunan kesehatan yang menyangkut upaya peningkatan kesehatan (promotif), pencegahan penyakit (preventif), penyembuhan penyakit (kuratif), dan pemulihan kesehatan (rehabilitatif) harus dilaksanakan secara menyeluruh, terpadu, dan berkesinambungan, serta bersama antara Pemerintahan dan masyarakat (Bastian, 2008).

Kesehatan ibu dan anak menjadi target dalam Millennium Development Goals (MDGs). Program kesehatan ibu dan anak menjadi sangat penting karena ibu dan anak merupakan unsur penting pembangunan, hal ini mengandung pengertian bahwa dari seorang ibu akan melahirkan calon-calon penerus bangsa yaitu anak. Untuk mendapatkan calon penerus bangsa yang akan dapat memberikan manfaat bagi bangsa maka harus diupayakan kondisi ibu dan anak yang sehat (Prasetyawati, 2012).

Mulyadi (2013) dalam Respati (2015) menyatakan pelayanan kesehatan adalah suatu organisasi untuk memelihara dan meningkatkan kesehatan, mencegah dan menyembuhkan penyakit, serta memulihkan kesehatan perseorangan, keluarga, kelompok, dan masyarakat. Peranan pelayanan dalam pelayanan kesehatan masyarakat adalah untuk memberikan pelayanan kepada pasien dengan sebaik mungkin.

Menurut Pohan (2013), pemberi layanan kesehatan harus memahami status kesehatan dan kebutuhan layanan kesehatan masyarakat yang dilayaninya dan mendidik masyarakat tentang layanan kesehatan dasar dan melibatkan masyarakat dalam menentukan bagaimana cara efektif menyelenggarakan layanan kesehatan.
Puskesmas sebagai salah satu institusi pelayanan kesehatan diharapkan dapat memberikan pelayanan kesehatan secara menyeluruh kepada masyarakat. Era globalisasi saat ini, Puskesmas dituntut untuk memenuhi keinginan dan memberi kepuasan kepada masyarakat dalam hal pelayanan kesehatan. Kepuasan pasien tersebut sangat tergantung kepada mutu pelayanan yang diberikan sehingga pasien dapat memenuhi keinginan dan kebutuhannya dalam menerima pelayanan yang diberikan oleh Puskesmas (Payaman, 2005). Berdasarkan hasil penelitian Rani (2013) di Puskesmas Padang Panyang Kecamatan Kuala Pesisir Kabupaten Nagan Raya Aceh Barat, terdapat hubungan antara ketersediaan sarana dan pelayanan petugas dengan kepuasan pasien.

Puskesmas Basuki Rahmad
merupakan salah satu Puskesmas di Kota Bengkulu yang terletak di Jalan Telaga Dewa RT 49 RW 04 Kelurahan Pagar Dewa, Kecamatan Selebar Kota Bengkulu, tergolong Puskesmas yang cukup ramai (Dinkes Kota Bengkulu, 2017). Berdasarkan hasil observasi yang dilakukan di Puskesmas Basuki Rahmad terjadi penurunan cakupan pelayanan KIA karena masih ada beberapa pasien yang mengeluhkan kondisi sarana prasarana serta pelayanan petugas.

Rumusan masalah dalam penelitian ini adalah "Apakah ketersedian sarana dan pelayanan petugas berhubungan dengan kepuasan pasien poli KIA di Puskesmas Basuki Rahmad Kota Bengkulu?". Tujuan penelitian ini adalah untuk mempelajari hubungan ketersediaan sarana dan pelayanan petugas dengan kepuasan pasien poli KIA di Puskesmas Basuki Rahmad Kota Bengkulu.

\section{Metode Penelitian}

Penelitian ini menggunakan jenis Survei Analitik dengan menggunakan desain Cross Sectional. Populasi dalam penelitian ini adalah pasien Ibu yang berkunjung di poli KIA di Puskesmas Basuki Rahmad Kota Bengkulu yaitu sebanyak 45 ibu dengan menggunakan teknik Accidental Sampling. Pengumpulan data menggunakan data primer dan sekunder. Analisis data menggunakan 
analisis univaiat dan bivariat dengan uji statistik Chi-Square $\left(\chi^{2}\right)$.

\section{Hasil Penelitian}

1. Analisis Univariat
Hasil analisis univariat dalam penelitian ini menggambarkan distribusi frekuensi ketersediaan sarana, pelayanan petugas, dan kepuasan pasien Poli KIA di Puskesmas Basuki Rahmad Kota Bengkulu yang dapat dijelaskan sebagai berikut :

Tabel 1

Distribusi Frekuensi Ketersediaan Sarana di Poli KIA Puskesmas Basuki Rahmad Kota Bengkulu

\begin{tabular}{cccc}
\hline No. & Ketersediaan Sarana & Frekuensi & Persentase (\%) \\
\hline 1. & Kurang Lengkap & 18 & 40,0 \\
2. & Lengkap & 27 & 60,0 \\
\hline & Jumlah & 45 & 100,0 \\
\hline
\end{tabular}

Dari Tabel 1 menunjukan bahwa dari $45 \mathrm{ibu}$, terdapat $18 \mathrm{ibu}(40,0 \%)$ mengatakan ketersediaan sarana kurang lengkap dan 27 ibu $(60,0 \%)$ mengatakan ketersediaan sarana lengkap.

Tabel 2

Distribusi Frekuensi Pelayanan Petugas di Poli KIA

Puskesmas Basuki Rahmad Kota Bengkulu

\begin{tabular}{clcc}
\hline No. & \multicolumn{1}{c}{ Pelayanan Petugas } & Frekuensi & Persentase $(\%)$ \\
\hline 1. & Kurang Baik & 14 & 31,1 \\
2. & Baik & 31 & 68,9 \\
\hline \multicolumn{2}{c}{ Jumlah } & 45 & 100,0 \\
\hline
\end{tabular}

Dari Tabel 2 menunjukkan bahwa dari $45 \mathrm{ibu,}$, terdapat $14 \mathrm{ibu}(31,1 \%)$ mengatakan pelayanan petugas kurang baik, dan 31 ibu $(68,9 \%)$ mengatakan pelayanan petugas baik.

Tabel 3

Distribusi Frekuensi Kepuasan Pasien di Poli KIA Puskesmas Basuki Rahmad Kota Bengkulu

\begin{tabular}{clcc}
\hline No & Kepuasan Pasien & Frekuensi & Persentase (\%) \\
\hline 1 & Tidak Puas & 18 & 40,0 \\
2 & Puas & 27 & 60,0 \\
\hline \multicolumn{2}{c}{ Jumlah } & 45 & 100,0 \\
\hline
\end{tabular}

Dari Tabel 3 menunjukkan bahwa dari $45 \mathrm{ibu}$, terdapat $18 \mathrm{ibu}(40,0 \%)$ mengatakan tidak puas, dan $27 \mathrm{ibu}(60,0 \%)$ mengatakan puas.

\section{Analisis Bivariat}

Analisis bivariat bertujuan untuk mengetahui hubungan antara variabel independent dengan variabel dependent pasien di Poli KIA Puskesmas Basuki Rahmad Kota Bengkulu. 
Tabel 4

Hubungan Ketersediaan Sarana dengan Kepuasan Pasien di Poli KIA

Puskesmas Basuki Rahmad Kota Bengkulu

\begin{tabular}{|c|c|c|c|c|c|c|c|c|}
\hline \multirow{3}{*}{$\begin{array}{c}\text { Ketersediaan } \\
\text { Sarana }\end{array}$} & \multicolumn{3}{|c|}{ Kepuasan Pasien } & \multirow{2}{*}{\multicolumn{2}{|c|}{ Total }} & \multirow{3}{*}{$\chi^{2}$} & \multirow{3}{*}{$\mathrm{p}$} & \multirow{3}{*}{$\mathrm{C}$} \\
\hline & $\begin{array}{l}\text { Tidak } \\
\text { Puas }\end{array}$ & \multicolumn{2}{|c|}{ Puas } & & & & & \\
\hline & $\mathrm{F} \quad \%$ & $\mathrm{~F}$ & $\%$ & $\mathrm{~F}$ & $\%$ & & & \\
\hline Kurang lengkap & 1477,8 & 4 & 22,2 & 18 & 100,0 & & & \\
\hline Lengkap & $4 \quad 14,8$ & 23 & 85,2 & 27 & 100,0 & 15,312 & 0,000 & 0,533 \\
\hline Total & 1840,0 & 27 & 60,0 & 45 & 100,0 & & & \\
\hline
\end{tabular}

Berdasarkan Tabel 4 dapat diketahui bahwa dari 18 ibu menyatakan ketersedian sarana kurang lengkap, terdapat 14 orang (77,8\%) ibu yang menyatakan tidak puas dan $4 \mathrm{ibu}(22,2 \%)$ yang menyatakan puas. Dari 27 ibu yang menyatakan ketersediaan sarana lengkap, terdapat 4 ibu $(14,8 \%)$ yang menyatakan tidak puas dan $23 \mathrm{ibu}(85,2 \%)$ yang menyatakan puas.

Hasil uji Chi-Square (Continuity Correction) didapatkan nilai $\chi^{2}=15,312$ dengan nilai $p=0,000<\alpha=0,05$, maka terdapat hubungan yang signifikan antara ketersediaan sarana dengan kepuasan pasien di Poli KIA Puskesmas Basuki Rahmad Kota Bengkulu. Hasil uji Contingency Coefficient didapat nilai 0,533 . Karena nilai tersebut tidak terlalu jauh dari nilai $\mathrm{C}_{\max }=0,707$ maka hubungan tersebut dikatakan kategori erat.

Tabel 5

Hubungan Pelayanan Petugas dengan Kepuasan Pasien di Poli KIA Puskesmas Basuki Rahmad Kota Bengkulu

\begin{tabular}{|c|c|c|c|c|c|c|c|c|c|}
\hline \multirow{3}{*}{ Pelayanan Petugas } & \multicolumn{4}{|c|}{ Kepuasan Pasien } & \multirow{2}{*}{\multicolumn{2}{|c|}{ Total }} & \multirow{3}{*}{$\chi^{2}$} & \multirow{3}{*}{$\mathrm{p}$} & \multirow{3}{*}{$\mathrm{C}$} \\
\hline & \multicolumn{2}{|c|}{$\begin{array}{l}\text { Tidak } \\
\text { Puas }\end{array}$} & \multicolumn{2}{|c|}{ Puas } & & & & & \\
\hline & $\mathrm{F}$ & $\%$ & $\mathrm{~F}$ & $\%$ & $\mathrm{~F}$ & $\%$ & & & \\
\hline Kurang Baik & 11 & 78,6 & 3 & 21,4 & 14 & 100,0 & & & \\
\hline Baik & 7 & 22,6 & 24 & 77,4 & 31 & 100,0 & 10,373 & 0,001 & 0,468 \\
\hline Total & 18 & 40,0 & 27 & 60,0 & 45 & 100,0 & & & \\
\hline
\end{tabular}

Berdasarkan Tabel 5 dapat diketahui bahwa dari 14 ibu yang menyatakan pelayanan petugas kurang baik, terdapat 11 ibu $(78,6 \%)$ yang menyatakan tidak puas dan $3 \mathrm{ibu}(21,4 \%)$ yang menyatakan puas. Dari 31 ibu yang menyatakan pelayanan petugas baik, terdapat $7 \mathrm{ibu}(22,6 \%)$ yang menyatakan tidak puas dan $24 \mathrm{ibu}(77,4 \%)$ yang menyatakan puas.
Hasil uji Chi-Square (Continuity Correction) didapat nilai $\chi^{2}=10.373$ dengan nilai $p=0,001<\alpha=0,05$, maka terdapat hubungan yang signifikan antara pelayanan petugas dengan kepuasan pasien di Poli KIA Puskesmas Basuki Rahmad Kota Bengkulu. Hasil uji Contingency Coefficient didapat nilai 0,468 . Karena nilai tersebut tidak terlalu jauh dari nilai $\mathrm{C}_{\max }=0,707$ maka hubungan tersebut dikatakan kategori sedang. 


\section{Pembahasan}

Berdasarkan hasil penelitian dapat diketahui bahwa dari 18 ibu yang menyatakan bahwa ketersediaan sarana di Poli KIA Puskesmas Basuki Rahmad kurang lengkap, terdapat 14 orang $(77,8 \%)$ yang menyatakan tidak puas, dan 4 orang $(22,2 \%)$ yang menyatakan puas. Hal ini karena, ibu mempunyai teman yang bekerja di Poli KIA di Puskesmas basuki Rahmad sehingga ibu tersebut merasa puas dan lebih mudah dalam prosedur pelayanan kesehatan.

Dari 27 ibu yang menyatakan bahwa ketersediaan sarana di Poli KIA Puskesmas Basuki Rahmad lengkap, terdapat 23 orang $(85,2 \%)$ yang menyatakan puas dan 4 orang $(14,8 \%)$ yang tidak puas. Hal ini karena, ibu menyatakan bahwa cara berkomunikasi petugas kurang nyaman bagi ibu, serta kondisi lingkungan Puskesmas juga kurang nyaman karena banyak yang sakit berobat disana. Menurut Aulia \& Putra (2014), terdapat hubungan yang bermakna antara komunikasi perawat dengan tingkat kepuasan pasien.

Berdasarkan hasil uji Chi-Square (Continuity Correction) menunjukkan terdapat hubungan yang signifikan antara ketersediaan sarana dengan kepuasan pasien di Poli KIA Puskesmas Basuki Rahmad Kota Bengkulu. Artinya bahwa ketersediaan sarana menentukan kepuasan pasien di Poli KIA Puskesmas Basuki Rahmad Kota Bengkulu..

Hasil uji Contingency Coefficient (C) diperoleh kategori hubungan erat, yang maknanya yaitu semakin lengkap ketersediaan sarana di Poli KIA akan meningkatkan kepuasan pasien dan sebaliknya semakin kurang lengkap ketersediaan sarana di Poli KIA akan mengurangi kepuasan pasien.

Penelitian ini sejalan dengan penelitian Rani (2013), yang hasil penelitiannya menunjukkan bahwa ada hubungan antara ketersediaan sarana dengan kepuasan pasien. Fasilitas atau ketersediaan sarana Puskesmas turut mempengaruhi kenyamanan, termasuk toilet, tempat duduk di ruang tunggu, jadi hal-hal tersebut bisa ditingkatkan untuk menjamin setiap pasien yang dirawat atau berobat merasa puas dengan kenyamanan Puskesmas.

Berdasarkan hasil analisis bivariat didapat bahwa dari14 ibu yang menyatakan kurang baik dengan pelayanan petugas di Poli KIA Puskesmas Basuki Rahmad terdapat 11 orang $(78,6 \%)$ yang menyatakan tidak puas dan 3 orang $(21,4 \%)$ yang menyatakan puas. Hal ini karena, ibu tersebut merasa ruangan pelayanan pemeriksaan tertata dengan baik dan rapi sehingga ibu tersebut merasa puas.

Dari 31 ibu yang menyatakan bahwa pelayanan petugas baik, terdapat terdapat 24 ibu $(77,4 \%)$ yang menyatakan puas dan $7 \mathrm{ibu}$ $(22,6 \%)$ yang tidak puas. Hal ini karena, ibu yang menyatakan tempat menunggu giliran di ruang Poli KIA kurang memadai, dan belum bisa menampung seluruh pasien yang menunggu sehingga menyebabkan pasien tidak puas.

Berdasarkan hasil uji Chi-Square (Continuity Correction) menunjukkan terdapat hubungan yang signifikan antara pelayanan petugas dengan kepuasan pasien di Poli KIA Puskesmas Basuki Rahmad Kota Bengkulu. Artinya pelayanan petugas menentukan kepuasan pasien di Poli KIA Puskesmas Basuki Rahmad Kota Bengkulu.

Hasil uji Contingency Coefficient (C) diperoleh kategori hubungan sedang. Artinya ada faktor lain yang berhubungan dengan kepuasan pasien di Poli KIA Puskesmas Basuki Rahmad Kota Bengkulu, yaitu ketersediaan sarana.

Penelitian ini sejalan dengan penelitian Rani (2013), yang hasil penelitiannya menunjukan ada hubungan antara pelayanan petugas dengan tingkat kepuasan pasien. Pelayanan petugas berhubungan dengan tugas para tenaga kesehatan di Puskesmas untuk menyelenggarakan kegiatan-kegiatan kesehatan sesuai dengan bidang keahlian dan atau kewenangan tenaga kesehatan yang bersangkutan. Tindakan atau cara petugas dalam melakukan pelayanan merupakan hal yang sangat mempengaruhi pasien terkait dengan kesembuhan penyakitnya. Adanya 
perlakuan yang baik dan penuh perhatian menjadi suatu daya tarik tersendiri dalam pemberian pelayanan kepada pasien. Hal ini memberikan kekuatan secara psikologis bagi pasien dan menumbuhkan motivasi untuk memanfaatkan layanan yang diberikan (Rumengan, Umboh, \& Kandau, 2015).

Menurut Purwatiningsih dalam Rumengan, Umboh, \& Kandau (2015), perbaikan mutu layanan sangat terkait dengan kecepatan tanggapan dan kehandalan tenaga kesehatan, peningkatan fasilitas kesehatan dan ketersediaan obat harus semakin ditingkatkan sehingga persepsi masyarakat terhadap program JKN juga semakin tinggi dan akhirnya pemanfaatan layanan Puskesmas semakin baik dalam arti bahwa Puskesmas menjadi pilihan utama masyarakat dalam mendapatkan pertolongan kesehatan.

Persepsi masyarakat terhadap pelayanan Puskesmas perlu ditingkatkan dengan memberikan pelatihan khusus yang terus menerus terhadap tenaga kesehatan mengenai penyakit atau masalah kesehatan di masyarakat sehingga kesigapan dan kecepatan dalam penanggulangan masalah kesehatan tersebut semakin baik. Adanya keterbatasan kemampuan dan ketrampilan tenaga kesehatan di Puskesmas dalam mengatasi penyakit memberi pengaruh terhadap kepercayaan masyarakat dalam berobat, untuk itu perlu dilakukan peningkatan kemampuan dan ketrampilan dalam pelayanan kesehatan sebagai upaya untuk meningkatkan kinerja petugas kesehatan (Purwatiningsih dalam Rumengan, Umboh, \& Kandau (2015)).

\section{Kesimpulan}

1. Dari 45 ibu yang berkunjung ke Poli KIA Puskesmas Basuki Rahmad Kota Bengkulu, terdapat $27 \mathrm{ibu}(60,0 \%) \mathrm{Ibu}$ mengatakan ketersediaan sarana lengkap.

2. Dari 45 ibu yang berkunjung ke Poli KIA Puskesmas Basuki Rahmad Kota Bengkulu, terdapat 31 ibu $(68,9 \%)$ mengatakan pelayanan petugas baik.

3. Dari 45 ibu yang berkunjung ke Poli KIA Puskesmas Basuki Rahmad Kota
Bengkulu, terdapat $27 \mathrm{ibu}(60,0 \%)$ merasa puas.

4. Terdapat hubungan yang signifikan antara ketersediaan sarana dengan kepuasan pasien di Poli KIA Puskesmas Basuki Rahmad Kota Bengkulu dengan kategori hubungan sedang.

5. Terdapat hubungan yang signifikan antara pelayanan petugas dengan kepuasan pasien di Poli KIA Puskesmas Basuki Rahmad Kota Bengkulu dengan kategori hubungan sedang.

\section{Daftar Pustaka}

Aulia, P. \& Putra, H. A. (2014). FaktorFaktor yang Berhubungan dengan Kepuasan Pasien dalam Pelayanan Keperawatan di Ruang Rawat Inap Interne Pria dan Wanita RSUD Dr. Achmad Mochtar Bukittinggi Tahun 2014. Diunduh dari http://www.ejournal.stikesyarsi.ac.id/ index.php/JAV1N1/article/view/42/1 $\underline{33 .}$

Bastian, I. (2008). Akuntansi Kesehatan, Yogyakarta : Penerbit Erlangga.

Dinkes Kota Bengkulu. (2017). Profil Kesehatan Kota Bengkulu 2016. Bengkulu : Dinkes Kota Bengkulu.

Payaman. (2005). Dasar-Dasar Keterampilan Manajerial. Jakarta : Bumi Aksara.

Pohan, I. S. (2013). Jaminan Mutu Layanan Kesehatan. Jakarta : EGC.

Prasetyawati, A. E. (2012). Kesehatan Ibu dan Anak (KIA) Dalam Millenium Development Goals (MDGs). Yogyakarta : Nuha Medika.

Rani, C. N. A. (2013). Evaluasi Tingkat Kepuasan Pasien Terhadap Pelayanan Kesehatan Dasar di Puskesmas Padang Panyang Kecamatan Kuala Pesisir Kabupaten Nagan Raya. Aceh Barat. Skripsi. Meulaboh : Program Studi Ilmu Kesehatan Masyarakat Fakultas Kesehatan Masyarakat Universitas Teuku Umar Meulaboh-Aceh Barat. Diunduh dari : http://repository.utu.ac.id/411/. 
Respati, S. A. (2015). Hubungan Mutu Pelayanan Kesehatan dengan Tingkat Kepuasan Pasien Rawat Inap di Puskesmas Halmahera Kota Semarang. Skripsi. Semarang : Jurusan Ilmu Kesehatan Masyarakat Fakultas Ilmu Keolahragaan Universitas Negeri Semarang. Diunduh dari :

https://lib.unnes.ac.id/20257/.
Rumengan, D. S. S., Umboh, J. M. L., \& Kandau, G. D. (2015). Faktor-Faktor yang Berhubungan dengan Pemanfaatan Pelayanan Kesehatan Pada Peserta BPJS Kesehatan di Puskesmas Paniki Bawah Kecamatan Mapanget Kota Manado. JIKMU, Suplemen, 5 (1) : 88-100. Diunduh dari

https://ejournal.unsrat.ac.id/index.php /jikmu/article/view/7180/7388. 